\title{
Distribution of Heavy Metals in Contaminated Water and Bottom Deposits of Manzala Lake, Egypt
}

Abd El-Monsef Ahmed El-Badry*

National Institute of Oceanography, Aswan Research Station, Egypt

\begin{abstract}
The pollution of the El-Manzala lake bottom sediment is indicative of water and food-web quality in general. Twenty five samples were collected from both water and surficial bottom sediments. Collaborating analytical techniques have been employed to analyze group of environment-sensitive elements, including; $\mathrm{Pb}, \mathrm{Cd}, \mathrm{Ni}, \mathrm{Co}, \mathrm{Cu}$, and $\mathrm{Zn}$. The present study documents serious pollution by $\mathrm{Cd}$, possibly as a result of using phosphate fertilizer. The average $\mathrm{Cd}$ content in the studied area is $17.5 \mathrm{ppm}$, which is about 36 fold the Maximum Permissible Limit (MPL=0.5 ppm) of soil. The highest concentration of $\mathrm{Cd}$ is $22.3 \mathrm{ppm}$, which is more than 45 fold the MPL. Cadmium is more mobile in aquatic environments than most other heavy metals. The areas around Port Said and El-Serw drain show marked pollution by most of the studied heavy metals. The main reason for such pollution is the industrial activities and agricultural drains. The unsupervised anthropogenic activities are the main causes of pollution in the studied lake. Routine program for monitoring the abundance and distribution of $\mathrm{Cd}$, and $\mathrm{Pb}$ in the studied bottom lake sediments, water, biota and food chain should be imposed.
\end{abstract}

Keywords: El-Manzala lake; Bottom sediments; Pollution; $\mathrm{Pb}$; Cd; $\mathrm{Ni}$; Co; Cu; Zn; Egypt

\section{Introduction}

Manzala Lake is located in the northeastern edge of the Nile Delta. It is bound by the Mediterranean Sea to the north, Port Said to the northeast, the Suez Canal to the east, El-Dakahlia Governorate on the southwest, El-Sharkia Governorate on the south, and Damietta on the west (Figure 1). It is the largest brackish water body located in the northeastern shoreline of the Nile Delta, and it lies between latitudes; $31^{\circ} 10^{\prime \prime}$ and $31^{\circ}$ $40^{\prime \prime} \mathrm{N}$ and longitudes; $31^{\circ} 50^{\prime \prime}$ and $32^{\circ} 25^{\prime \prime} \mathrm{E}$. It is a shallow brackish water lagoon, with a depth ranging between 0.2 and $2 \mathrm{~m}$.

At present, the lake area covers about $\sim 1071 \mathrm{~km}^{2}$, with maximum length of $64.5 \mathrm{~km}$ and maximum width of $49 \mathrm{~km}$. The original area of ElManzala lake was more than $1700 \mathrm{~km}^{2}$ in 1900 . The area of the lagoon has been reduced to $1200 \mathrm{~km}^{2}$ by 1980 as a result of land reclamation. It water has a brackish nature, mixed with sea water through Boughaz El -Gamil opening (12.5 km west of Port Said) at the north eastern side of the lake.

\section{Pollution sources}

Manzala Lake is one of the most polluted lakes in Egypt. The sediments act as "sink" for metal contaminants, and risk increases with increasing metals leachability. The impact of such heavy metals abnormality may extend to involve the water quality and food web, and hence to the human health. In the studied area, source(s) of the toxic metals could be natural or anthropogenic. This is contributed by industrial, domestic, human activities, sewage and huge amounts of agriculture brackish water wastes from drainage system at all direction. The most widely recognized issue is that of agricultural drains as Hados, Bahr El-Baqar and Ramses drains which open into the southern beach of the lake.

The water quality and pollution of El-Manzala lake has been the objective of many authors El-Wakeel and Wahby [1], Abdel-Mouti [2], Abdel-Mout and Dowidar [3], El-Sabrouti [4], Hussein [5], AbdelSatar [6], Dewidar and Khedr [7], Lotfy [8,9], Abdalla [10], Orabi [11].

The main objective of this study is mainly to assess the suitability of the lake for fish industry according the international constrains imposed by the Egyptian standards and the world-wide organizations such as; WHO, EPI, and FAO. Increasing awareness of pollution risk may support the implemented mitigation and remediation programs to face the rapid deterioration of this important marine ecosystem.

\section{Materials and Methods}

Samples of both water and surficial bottom sediments were collected from 25 locations represent the Manzala Lake during summer

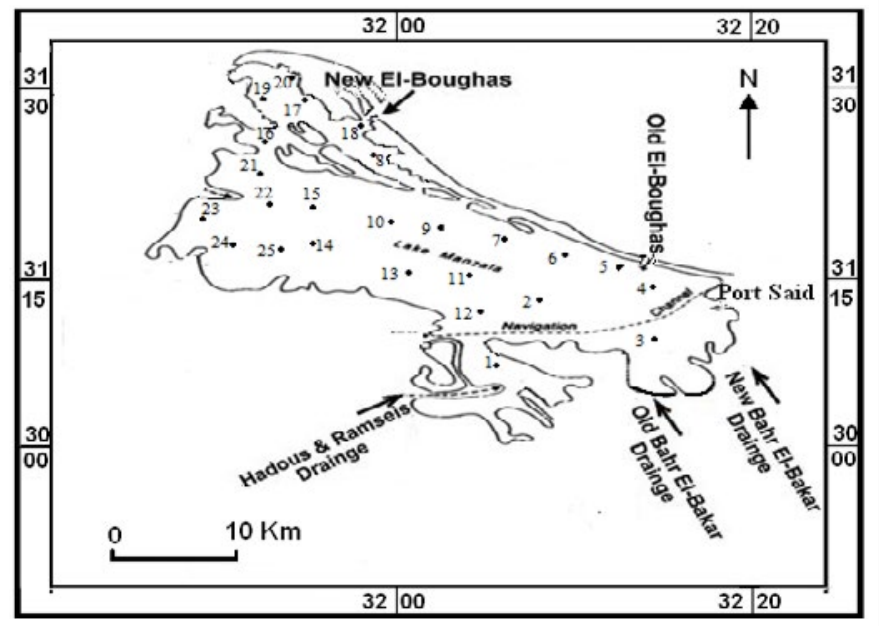

Figure 1: Key map of Manzala Lake showing the location sampled sites.

*Corresponding author: Abd El-Monsef Ahmed El-Badry, National Institute of Oceanography, Aswan Research Station, Egypt, Tel: 01111440884; E-mail: monsef1958@yahoo.com

Received October 29, 2015; Accepted December 31, 2015; Published January 04, 2016

Citation: El-Badry AEA (2016) Distribution of Heavy Metals in Contaminated Water and Bottom Deposits of Manzala Lake, Egypt. J Environ Anal Toxicol 6: 344 doi:10.4172/2161-0525.1000344

Copyright: $\odot 2016$ El-Badry AEA. This is an open-access article distributed under the terms of the Creative Commons Attribution License, which permits unrestricted use, distribution, and reproduction in any medium, provided the original author and source are credited. 
2014 (Figure 1). The sampled stations were chosen to cover the most of the studied area. Samples were essentially taken from the upper $50 \mathrm{~cm}$ of the Manzala Lake bottom sediments at water depth ranging from $20 \mathrm{~cm}$ to 2 meters. After air drying, samples were disintegrated and representative quotient was thoroughly pulverized to -100 mesh size, and then kept for chemical analyses. The chemical analyses were conducted on whole sediment samples for the trace elements; $\mathrm{Pb}, \mathrm{Ni}$, $\mathrm{Co}, \mathrm{Cu}, \mathrm{Zn}$ and $\mathrm{Cd}$ using atomic absorption spectrometry (PerkinElmer 3110, USA) with graphite atomizer HGA-600, after using the digestion technique according to the standard APHA [12]. The Physico-chemical parameters namely; $\mathrm{pH}, \mathrm{Ec}$, and total dissolved salts were measured. The former was measured by an Orient Research pHmeter, Model 20. Total dissolved salts, were determined also according to APHA [12]. The preparation of water and sediment for trace metal determination was carried out according the method described in FAO technical paper No.158.

\section{Results and Discussion}

\section{Physico-chemical parameters}

Water depth: Manzala Lake is characterized by its very shallow water due to silting up of sediment originated from the high load of discharged particles from the drains. The highest average depth was recorded at eastern portion of the lake $(2 \mathrm{~m})$, while the lowest depth $(20$ $\mathrm{cm})$ was recorded at rest of the lake and in front of drain.

Hydrogen ion concentration (pH): The $\mathrm{pH}$ values play an important role as indicator of pollution levels and control many biological processes. The maximum value of $\mathrm{pH}$ (9.65) was recorded at the northern beach of the lake far away from the effects of discharges of the drains in southern side related to the high fertility and increase in the total count of phytoplankton (Figure $2 \mathrm{~A}$ ). The lowest $\mathrm{pH}$ value was recorded due the southwards of the lake (7.68) and attributed to the effect of pollution due to the liberation of $\mathrm{CO}_{2}$ and $\mathrm{H}_{2} \mathrm{~S}$ during the decomposition of organic matters, in addition of load of discharges and organic matter.

Electrical conductivity $(\mathrm{Ec})$ : The electrical conductivity varies, in the lake water, between $3400 \mu \mathrm{mhos} / \mathrm{cm}$ and $11900 \mu \mathrm{mhos} / \mathrm{cm}$, averaging $7680 \mu \mathrm{mhos} / \mathrm{cm}$. It increases gradually northwards, due to the inflow of sea water through the main connection between the lake and the sea and also to the inflow of agriculture wastewater at southwestern ward through El-Serw drain (Figure 2B).

Total dissolved salts (TDS): TDS in Manzala Lake was mainly affected by the drainage water discharged into the lake, the invasion of sea water through the lake-sea connection, the high rates of evaporation, in addition to wind action. The highest value of total dissolved salts was recorded in the eastern portion of the lake near to El-Boughaz opening $(17.56 \mathrm{mg} / \mathrm{L})$ affected by sea water. This value decreases to its lowest value of $0.995 \mathrm{mg} / \mathrm{L}$ in the middle sector with an average of $4.47 \mathrm{mg} / \mathrm{L}$ (Figure 2C).

\section{Heavy metals in lake water}

The total heavy metals content of the investigated water are given in Table 1. The concentration of Cadmium ranges from 0 to $1.5 \mu \mathrm{g} / \mathrm{L}$ with an average of $0.4 \mu \mathrm{g} / \mathrm{L}$. Lead ranges from $1.9 \mu \mathrm{g} / \mathrm{L}$ to $14.5 \mu \mathrm{g} / \mathrm{L}$ with an average $5.8 \mu \mathrm{g} / \mathrm{L}$. Zinc ranges from $0.1 \mu \mathrm{g} / \mathrm{L}$ to $2.2 \mu \mathrm{g} / \mathrm{L}$, with an average $0.9 \mu \mathrm{g} / \mathrm{L}$ while Nickel from $0.82 \mu \mathrm{g} / \mathrm{L}$ to $8.55 \mu \mathrm{g} / \mathrm{L}$ with an average $2.44 \mu \mathrm{g} / \mathrm{L}$. Cupper ranges from $2.1 \mu \mathrm{g} / \mathrm{L}$ to $3.6 \mu \mathrm{g} / \mathrm{L}$ with an average $2.8 \mu \mathrm{g} / \mathrm{L}$ whereas Cobalt ranges from $1 \mu \mathrm{g} / \mathrm{L}$ to $2.17 \mu \mathrm{g} / \mathrm{L}$ with an average $1.45 \mu \mathrm{g} / \mathrm{L}$ (Figure 3 ).

\section{Geochemical backgrounds}

The comparison between the present data and the average earth's crust as quoted by McLennan and Taylor [13] is given in Table 2. The comparison suggests the following inferences:

- The average contents of $\mathrm{Co}, \mathrm{Pb}$, and $\mathrm{Ni}$ in the studied sediments $(110,79,228 \mathrm{ppm})$ are about 6,4 and 3 fold the average earth's crust, respectively

- Cd (from 5 to $22.3 \mathrm{ppm}$ ) is more than 20 and up to 65 fold the average earth's crust. Not like other heavy metal, Zn (130 ppm) is slightly higher than average earth's crust, while $\mathrm{Cu}(19.74 \mathrm{ppm}$ in average) is eventually depleted to less than half the content of the crust.

Comparing with the US Public Health Service, which established the freshwater sediment quality guidelines in the form of level of probable effects, the studied sediments seem to be polluted at different levels (Table 3 ). The analyzed heavy metals $(\mathrm{Co}, \mathrm{Cu}, \mathrm{Ni}, \mathrm{Zn}$, and $\mathrm{Cd}$, $\mathrm{Pb}$ ) are not intimately correlated to each other as they have different speciation and sources. The elements; $\mathrm{Pb}$. Ni, $\mathrm{Co}, \mathrm{Zn}$ and $\mathrm{Cd}$ are strongly related to moderately correlate (Figure $4 \mathrm{~A}$ ).

\section{The regional pollution index (RPI)}

The degree of pollution of the El-Manzala lake bottom sediments can be calculated by normalizing the metals concentration to their Maximum Permissible Limits (MPL) used for the worldwide soil. In the given equation of the pollution index, the MPL of an element is

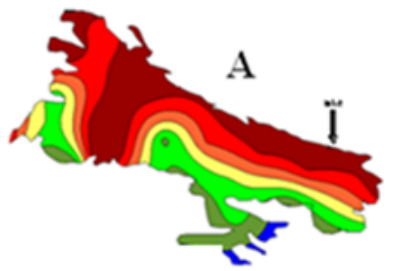

PH value
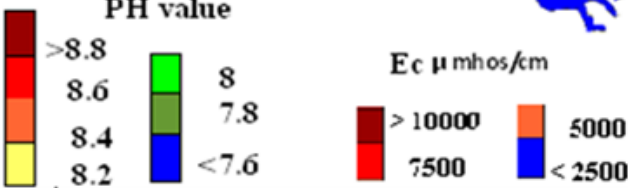

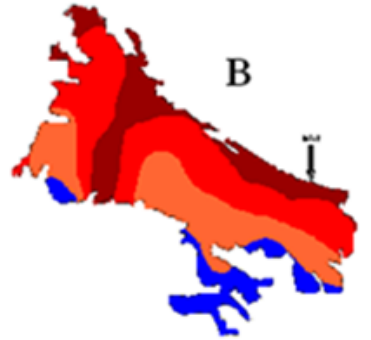

000

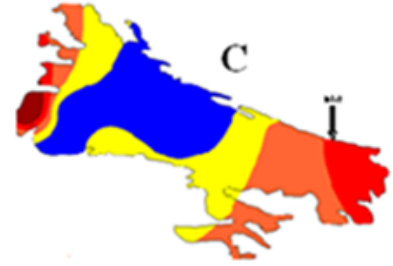

$\mathrm{TDS}$ in $\mathrm{mg} / \mathrm{L}$

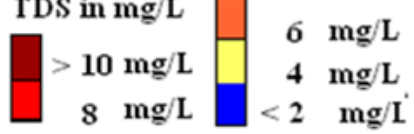

Figure 2: Distribution of $\mathrm{pH}$ value, electrical conductivity and Total Dissolved Salts (TDS) in the water of Manzala Lake. 
Citation: El-Badry AEA (2016) Distribution of Heavy Metals in Contaminated Water and Bottom Deposits of Manzala Lake, Egypt. J Environ Anal Toxicol 6: 344. doi:10.4172/2161-0525.1000344

Page 3 of 8

\begin{tabular}{|c|c|c|c|c|c|c|}
\hline Sample & $\mathrm{Pb}$ & $\mathrm{Cu}$ & Cd & $\mathrm{Zn}$ & Co & $\mathrm{Ni}$ \\
\hline 1 & 8.5 & 2.2 & 0.4 & 1.6 & $\mathrm{Nm}$ & 1.75 \\
\hline 2 & 7.1 & 3.0 & 0.5 & 0.7 & 1.32 & 2.58 \\
\hline 3 & 7.1 & 2.1 & 0.4 & 0.9 & 1.11 & 2.88 \\
\hline 4 & 10.4 & 3.5 & 0.9 & 1.0 & 1.44 & 5.25 \\
\hline 5 & 14.5 & 2.9 & 1.5 & 1.8 & 1.51 & 8.55 \\
\hline 6 & 8.2 & 2.2 & 0.7 & 0.9 & 1.37 & 4.12 \\
\hline 7 & 8.9 & 3.2 & 0.6 & 0.9 & 1.30 & 3.61 \\
\hline 8 & 5.5 & 3.0 & 0.3 & 0.5 & 1.68 & 2.06 \\
\hline 9 & 4.8 & 2.7 & 0.0 & 0.2 & 1.52 & 0.93 \\
\hline 10 & 6.4 & 2.9 & 0.2 & 0.3 & 1.00 & 1.65 \\
\hline 11 & 4.6 & 3.1 & 0.0 & 0.6 & 1.64 & 0.93 \\
\hline 12 & 4.0 & 2.7 & 0.1 & 0.2 & 1.28 & 1.34 \\
\hline 13 & 2.9 & 2.8 & 0.2 & 0.2 & 1.28 & 0.82 \\
\hline 14 & 3.9 & 2.7 & 0.0 & 0.1 & 1.92 & 1.24 \\
\hline 15 & 5.7 & 3.0 & 0.1 & 0.5 & 2.17 & 2.16 \\
\hline 16 & 6.0 & 3.0 & 0.1 & 1.4 & $\mathrm{Nm}$ & 1.85 \\
\hline 17 & 4.0 & 2.8 & 0.1 & 0.9 & $\mathrm{Nm}$ & 0.82 \\
\hline 18 & 5.7 & 2.9 & 0.1 & 1.1 & $\mathrm{Nm}$ & 1.75 \\
\hline 19 & 5.7 & 2.9 & 0.2 & 1.2 & $\mathrm{Nm}$ & 2.16 \\
\hline 20 & 10.0 & 3.6 & 0.8 & 2.2 & $\mathrm{Nm}$ & 5.8 \\
\hline 21 & 1.9 & 2.4 & 0.3 & 0.9 & 1.54 & $\mathrm{Nm}$ \\
\hline 22 & 2.1 & 3.6 & 0.8 & 1.4 & 1.62 & $\mathrm{Nm}$ \\
\hline 23 & 2.0 & 2.5 & 0.4 & 0.5 & 1.15 & $\mathrm{Nm}$ \\
\hline 24 & 2.7 & 2.4 & 0.4 & 1.1 & 1.29 & $\mathrm{Nm}$ \\
\hline 25 & 2.8 & 2.7 & 0.3 & 0.9 & $\mathrm{Nm}$ & $\mathrm{Nm}$ \\
\hline Average & 5.8 & 2.8 & 0.4 & 0.9 & 1.45 & 2.44 \\
\hline Maximum & 14.5 & 3.6 & 1.5 & 2.2 & 2.17 & 8.55 \\
\hline Minimum & 1.9 & 2.1 & 0.0 & 0.1 & 1.00 & 0.82 \\
\hline
\end{tabular}

$\mathrm{Nm}$ : Not measured

Table 1: Concentrations of trace elements in surface water of Manzala Lake $(\mu \mathrm{g} / \mathrm{L})$.

considered as the "pollution standard level or goal". The index of an individual pollutant is calculated as follows:

$$
\text { Index }=\frac{\text { Pollution concentration } \times 50}{\text { Pollutant standard level or goal }}
$$

For each region, the highest calculated index is used as the RPI for that region. An RPI of 50 corresponds to the relevant standard/goal. The RPI is categorized as low, medium or high, as follows:

- Low pollution index from 0 to 24

- Medium pollution index from 25 to 49

- High pollution index 50 or higher.

Table 3 summarizes the RPI of the studied Manzala Lake bottom sediments. It can be concluded that the studied area is exposed to high pollution levels by $\mathrm{Cd}, \mathrm{Pb}, \mathrm{Ni}$ and $\mathrm{Co}$, whereas $\mathrm{Zn}$ and $\mathrm{Cu}$ display low degree of pollution.

\section{Heavy metals in lake sediments}

The following is a brief discussion on the environmental status of organic matter and some metals that may bear some risk or endanger on human environment beside the geochemical distribution maps of potentially toxic metals.
The total heavy metals content of the investigated sediments are given in Table 4.

Organic matter: The organic matter content ranges between 1.24 and $12.14 \%$, with an average of $6.45 \%$. The lowest value was recorded in the eastern portion of the lake, but the content increases toward the western side where el-Serw agricultural drain is located (Figure 5A).

Lead (Pb): Among all metals; $\mathrm{Pb}, \mathrm{Cd}$ and $\mathrm{Zn}$ are in the closest relationship to humans; however, $\mathrm{Pb}$ is damaging to the human body. In the present work, the total lead content ranges from 19.6 to 153.6 $\mathrm{ppm}$, with an average of $78.48 \mathrm{ppm}$ (Figure 4B). The lowest value is recorded at middle portion of the lake while the highest values are recorded near el-Serw agricultural drain and, also, at eastern portion of the lake where the industrial region in Port Said country (Figure 5B).

The MPL of $\mathrm{Pb}$ in the worldwide soils is $20 \mathrm{ppm}$. According to the Agency for Toxic Substances and Disease Registry, soil contamination by lead from mine tailings may be less effective in increasing $\mathrm{PbB}$ (blood lead) levels than its lead contamination derived from urban lead pollution.

Cadmium (Cd): It is more mobile in aquatic environments than most other heavy metals, e.g., $\mathrm{Pb}$. Igneous and metamorphic rocks have low values of $\mathrm{Cd}$ from 0.02 to $0.2 \mathrm{ppm}$, whereas sedimentary rocks may have higher values ( 0.1 to $25 \mathrm{ppm}$ ). According to Kabata-Pendias 

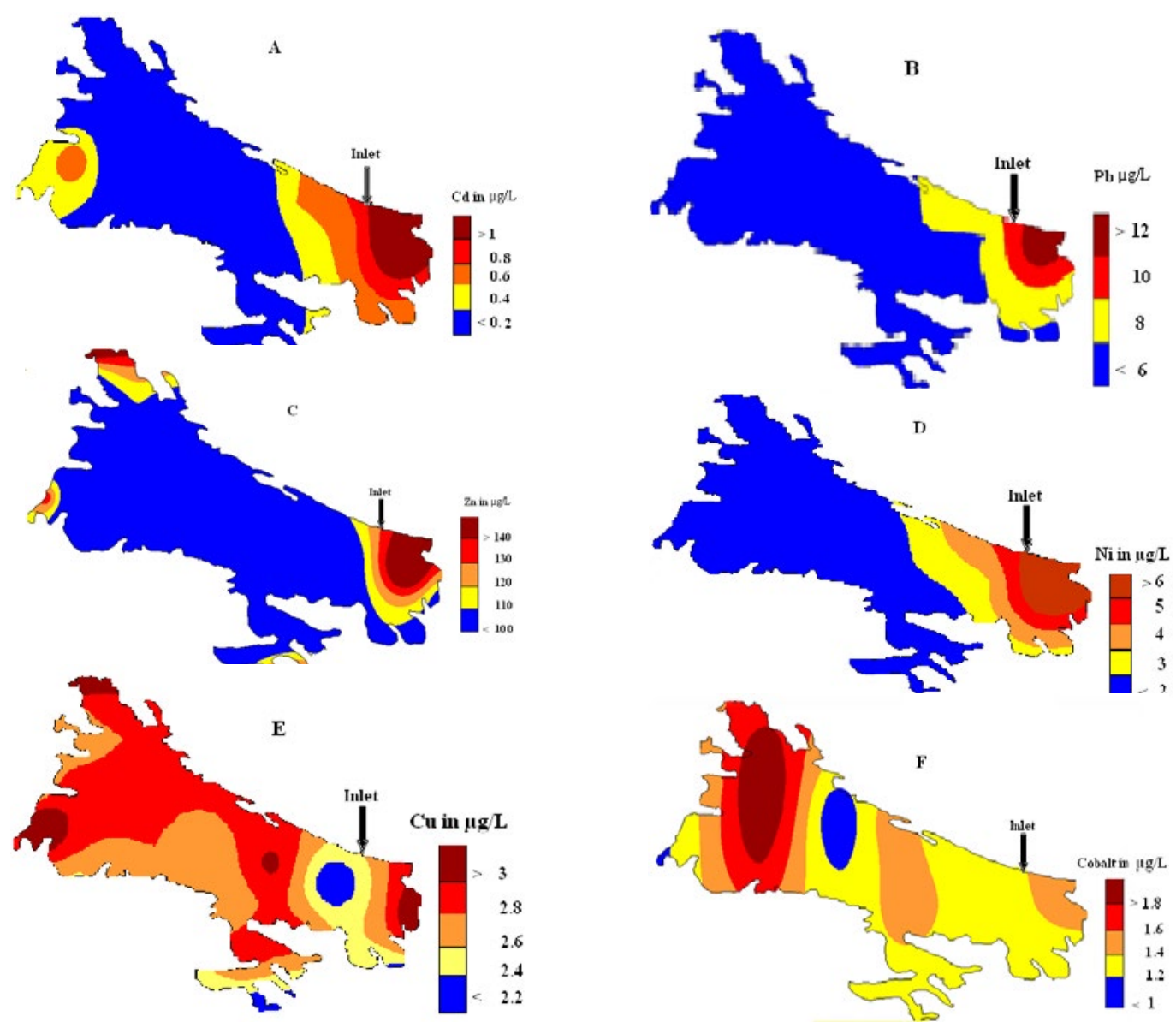

Figure 3: Spatial distribution map of the analyzed potentially toxic metals in the studied lake water (A) Cadmium, (B) Lead, (C) Zinc, (D) Nickel, (E) Cupper and (F) Cobalt $(\mu \mathrm{g} / \mathrm{L})$.

\begin{tabular}{|c|c|c|c|c|c|c|c|c|}
\hline Elements & Present Study & Abdalla (2003) & Ghallb (2007) & Lotfy (2007) & $\begin{array}{c}\text { Average share } \\
\text { of Mason and } \\
\text { Moor, 1982 }\end{array}$ & $\begin{array}{c}\text { Solomns \& } \\
\text { Forest (1984) }\end{array}$ & $\begin{array}{c}\text { Fresh water } \\
\text { sediments } \\
\text { (USPH, 1997) }\end{array}$ & $\begin{array}{c}\text { Earth crust } \\
\text { McLennan and } \\
\text { Taylor (1999) }\end{array}$ \\
\hline $\mathrm{Pb}$ & 78 & 9 & 21 & 51 & 20 & 19 & 20 \\
\hline $\mathrm{Cu}$ & 20 & 40.5 & 19.33 & 20.7 & 50 & 33 & 45 \\
\hline $\mathrm{Cd}$ & 18 & $\mathrm{Nd}$ & 28 & 21 & 0.3 & 0.11 & 1 \\
\hline $\mathrm{Zn}$ & 130 & 71.5 & 44 & 62 & 90 & 95 & $<100$ \\
\hline $\mathrm{Ni}$ & 228 & 46.3 & $\mathrm{Nd}$ & 49 & 80 & $\mathrm{Nd}$ & 45 \\
\hline $\mathrm{Co}$ & 110 & 19.5 & $\mathrm{Nd}$ & $\mathrm{Nd}$ & 20 & $\mathrm{Nd}$ & $\mathrm{Nd}$ \\
\hline $\mathrm{Fe}$ & 10799 & 34500 & 3220 & 58000 & 47000 & 4100 & 10 \\
\hline
\end{tabular}

Table 2: Average heavy metals of the present work compared with average earth crust McLennan and Taylor [13], and averages of published data (contents are given in ppm).

[14], the Maximum Permissible Limit (MPL) of Cd in cultivated soil is $0.5 \mathrm{ppm}$. The Department of Health and Human Services (DHHS) has determined cadmium and cadmium compounds as carcinogens; therefore, the Environmental Protection Agency (EPA) has set a limit of $5 \mathrm{ppb}$ of cadmium for drinking water. In the present study, the $\mathrm{Cd}$ content ranges from 5.9 to $22.3 \mathrm{ppm}$ with an average value of $17.5 \mathrm{ppm}$. The frequency distribution of Cd is unimodal with maximum at about 15-20 ppm (Figure 4C). The distribution pattern is strongly skewed towards the higher concentrations. Therefore, the average content of $\mathrm{Cd}$ in the study area is more than 36 fold the MPL of soil as quoted by Kabata-Pendias. While the highest Cd content $(22.3 \mathrm{ppm})$ is more than 48 fold.

Generally, Cd being more mobile in aquatic environments than most other heavy metals, it can be a serious pollutant for the lake bottom sediments. It is mostly related to phosphate fertilizers at ElSerw agriculture drain, also possible source where $\mathrm{Cd}$ is the combustion of fossil fuel and some industrial activities at western portion of the studied lake (Figure 5C).

Cobalt: Co content ranges between 71 and 164 ppm, averaging 110 ppm (Figure 4D). This average value is more than two fold of the MPL 
Citation: El-Badry AEA (2016) Distribution of Heavy Metals in Contaminated Water and Bottom Deposits of Manzala Lake, Egypt. J Environ Anal Toxicol 6: 344. doi:10.4172/2161-0525.1000344

Page 5 of 8

\begin{tabular}{|c|c|c|c|c|}
\hline Elements & Present study $(\mathbf{p p m})$ & MPL (ppm) & RPI & 1754 \\
\hline $\mathrm{Cd}$ & 18 & 0.5 & 10 \\
\hline $\mathrm{Cu}$ & 20 & 100 & High \\
\hline $\mathrm{Ni}$ & 228 & 100 & 114 \\
\hline $\mathrm{Co}$ & 110 & 50 & 110 \\
\hline $\mathrm{Zn}$ & 130 & 300 & 22 \\
\hline $\mathrm{Pb}$ & 78 & 20 & High & \\
\hline
\end{tabular}

Table 3: Average heavy metals of the present work compared to the average of the Maximum Permissible Limit (MPL) in the worldwide soils [14] and Regional Pollution Index (RPI).
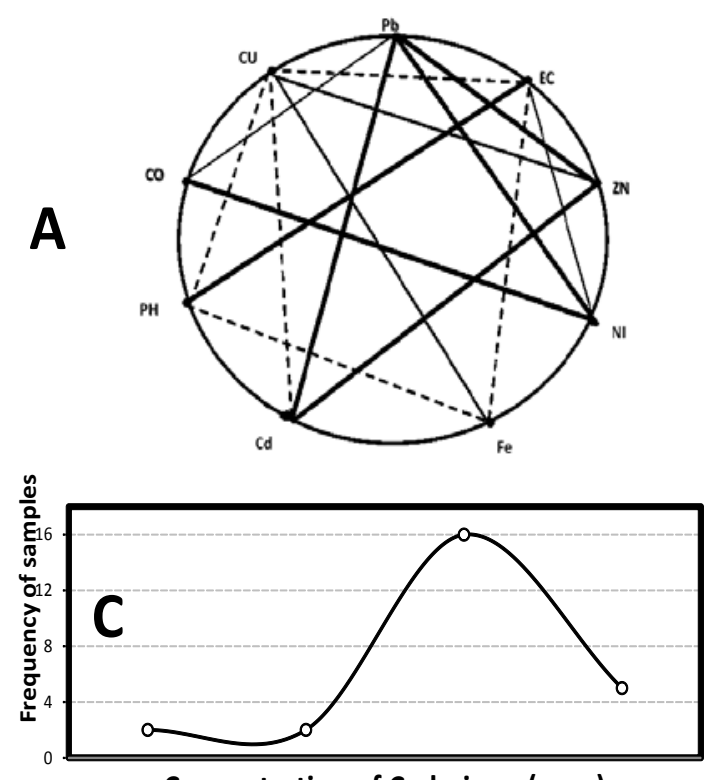

${ }_{10}$ Concentration of Cadmium (ppm)>20
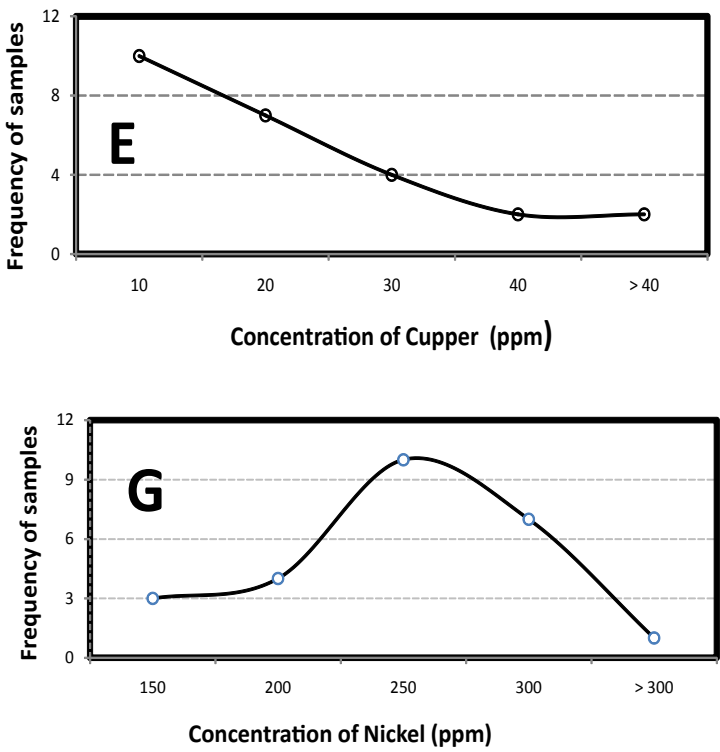
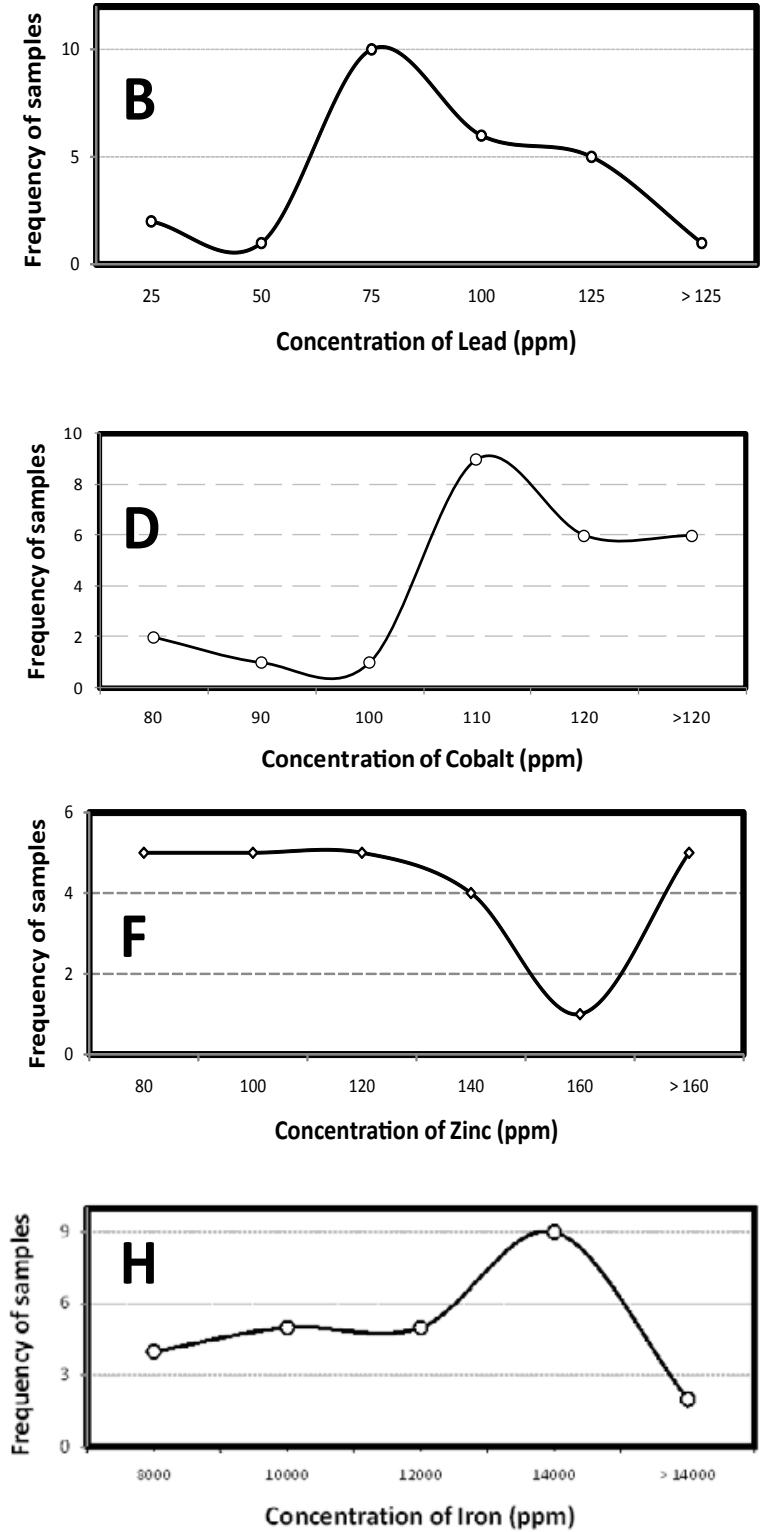

Figure 4: Correlations among the analyzed heavy metals $(A)$. The intensity of lines corresponds to the strength of the correlation coefficient. The dotted line means weak or reversed relation. Frequency distribution, in ppm, of lead (B), cadmium (C), cobalt $(D)$, copper $(E)$, zinc $(F)$, nickel $(G)$ andiron $(H)$ in the studied area. 


\begin{tabular}{|c|c|c|c|c|c|c|c|c|}
\hline Station No. & $\mathrm{Pb}$ & $\mathrm{Cu}$ & Cd & $\mathrm{Zn}$ & $\mathrm{Ni}$ & Co & $\mathrm{Fe}$ & om \\
\hline 1 & 79.8 & 6.9 & 18.5 & 76.3 & 198.8 & 104.5 & 6219 & 7.6 \\
\hline 2 & 22.2 & 2.9 & 14.3 & 70.3 & 149.8 & 81.3 & 6346 & 8.1 \\
\hline 3 & 83.7 & 5.5 & 19.5 & 97.4 & 258.1 & 119.1 & 6518 & 5.5 \\
\hline 4 & 56.6 & 5 & 16.2 & 65.1 & 187.7 & 101.3 & 7058 & 4.9 \\
\hline 5 & 124.3 & 10.4 & 22.1 & 120.6 & 264.7 & 125.1 & 8028 & 1.6 \\
\hline 6 & 67.4 & 12.4 & 18.4 & 164.1 & 218.8 & 107.1 & 9252 & 3.7 \\
\hline 7 & 124.3 & 13.7 & 20.6 & 111.3 & 268.5 & 126.4 & 9290 & 6.9 \\
\hline 8 & 52.1 & 5.3 & 16.6 & 87.3 & 210.9 & 105.6 & 9322 & 8.3 \\
\hline 9 & 71 & 3.3 & 19 & 67.4 & 186.4 & 92.7 & 9650 & 4.0 \\
\hline 10 & 82.1 & 4.7 & 19.9 & 73.5 & 216.4 & 106.5 & 10520 & 8.8 \\
\hline 11 & 90.2 & 8.5 & 19.8 & 94.9 & 248.6 & 112.8 & 10730 & 4.6 \\
\hline 12 & 91 & 8.5 & 19.2 & 109.5 & 248.6 & 114.6 & 10780 & 4.6 \\
\hline 13 & 63 & 10 & 17.6 & 114.8 & 232.3 & 108.9 & 11060 & 4.1 \\
\hline 14 & 107.4 & 26.5 & 21.3 & 106.4 & 255 & 115.7 & 11380 & 11.6 \\
\hline 15 & 67.9 & 15.4 & 17.3 & 95.5 & 237.5 & 109.1 & 12150 & 7.5 \\
\hline 16 & 62.8 & 20.8 & 18.5 & 127.7 & 241.9 & 111.3 & 12210 & 12.1 \\
\hline 17 & 63.2 & 78.4 & 5.9 & 218.2 & 117.7 & 70.8 & 12300 & 1.2 \\
\hline 18 & 67.5 & 10.1 & 17.9 & 95.8 & 249.7 & 115.5 & 12650 & 7.3 \\
\hline 19 & 108.5 & 24 & 22.3 & 209.3 & 294.3 & 131.7 & 12850 & 9.4 \\
\hline 20 & 32.8 & 16.8 & 16.5 & 104.4 & 196.9 & 102.8 & 12910 & 6.0 \\
\hline 21 & 19.6 & 37 & 5.9 & 124.6 & 137.3 & 70.8 & 13140 & 3.6 \\
\hline 22 & 67.9 & 29.8 & 17 & 163.9 & 260.8 & 120.2 & 13510 & 7.2 \\
\hline 23 & 118.8 & 17.8 & 22 & 139.7 & 301.5 & 164.4 & 13890 & 9.7 \\
\hline 24 & 153.6 & 86.5 & 14.8 & 461.8 & 231.4 & 107.5 & 14080 & 10.6 \\
\hline 25 & 84.3 & 33.2 & 17.4 & 150.2 & 281.3 & 131.4 & 14130 & 2.6 \\
\hline Average & 78.5 & 19.7 & 17.5 & 130.0 & 227.8 & 110.3 & 10798.9 & 6.5 \\
\hline
\end{tabular}

Table 4: Concentrations of trace elements in bottom sediments of Manzala Lake.

recorded for the worldwide soil (50 ppm) as quoted by Kabata-Pendias [14]. The content of Co increses tword the eastern side of the studied lake, due to industerial activites in Port Said country. Other focuse of polution has been distinguihed near El-Serw agricultural drain (Figure 5D) [15].

Copper: Its content ranges from 2.9 to 86.5 ppm, averaging 19.7 (Figure 4E). The highest content is almost equal to the MPL (100 ppm). According to Kabata-Pendias [14], the simple frequency distribution of $\mathrm{Cu}$ in the studied sediments indicates that $80 \%$ of the analyzed samples contain below $30 \mathrm{ppm}$, while $20 \%$ of the samples contain $>30 \mathrm{ppm}$ (Figure 5E). It was noticed that $\mathrm{Cu}$ content increases gradually toward the south eastern portion of the lake due to Bahr el Baqar drain, with several anomalous patches near the main cities and close to Damietta country, which seems to be the main industrially polluted [16,17].

Zinc: In the studied lake ranges between 65.1 and $461.8 \mathrm{ppm}$, averaging $130 \mathrm{ppm}$. The content increases due south eastern portion, due to industerial activity in Port Said country (Figure 5F).

Nickel: It is considered as a very toxic element. In the present study, Ni content ranges between 117 and 302 ppm, averaging 228 $\mathrm{ppm}$. This average value is more than two fold the MPL recorded for the worldwide soil (100 ppm), as quoted by Kabata-Pendias [14]. The frequency distribution of the $\mathrm{Ni}$ is unimodal with maximum at about 200-250 ppm. Ni is concentrated at the eastern part of the lake due to industrial activity near Port Said. Fe also accumulates at the northwestern side of the studied area, close to El Serw drain and the industrial region of Damietta (Figure 5G) [18].

Iron: In the present study, Fe content ranges between $6219 \mathrm{ppm}$ and $14130 \mathrm{ppm}$, averaging $10800 \mathrm{ppm}$. The frequency distribution of the $\mathrm{Fe}$ is unimodal with maximum at about $12000-14000 \mathrm{ppm}$. Fe content is concentrated at southeastern portion of the lake towards
Bahr el Baqar drain, also Fe accumulated at northwestern side where Mohib drain and Damietta industrial region (Figure 4H) [19].

\section{Total heavy metals}

In general, the heavy metals; lead, copper, cadmium, zinc, cobalt and nickel, produce their toxicity by forming complexes or "ligands" with organic compounds. In the studied sediments the heavy metals distribution pattern is not uniform and it seems to be more likely related to anthropogenic activities. It shows gradual increase of pollution towards el-Serw agricultural drain and the second order level of pollution is recorded near the main cities where Industrial district in Port Said country at eastern portion of the lake and Damietta country at the west of the lake (Figure 6) [20-22].

\section{Conclusions}

In northern lakes of Egypt Manzala lake receives greet quantity of agricultureal, industerial, municipal annd domestic wastwater, in addition to navigation and fishing activities. Generally, the highest concentrations of $\mathrm{Cd}, \mathrm{Pb}, \mathrm{Ni}$ and $\mathrm{Zn}$ in water were observed in the eastern portion of the lake where industrial zone of Port Said country whiles the lowest values were recorded at the western portion of the lake. Highest $\mathrm{Cu}$ and $\mathrm{Co}$ values were recorded in the western area towards el-Serw agricultural drain. The relative order of abundance of the potentially toxic metals in the lake's water is; $\mathrm{Pb}>\mathrm{Cu}>\mathrm{Zn}>\mathrm{Cd}$. The present work is based on chemical analysis data on the bottom sediments of the Manzala Lake, relative to average earth's crust, the lake sediments are markedly enriched in $\mathrm{Cd}, \mathrm{Ni}, \mathrm{Co}$, and $\mathrm{Pb}$, and slightly enriched in $\mathrm{Cu}$ and $\mathrm{Zn}$. The calculated pollution index nominates $\mathrm{Cd}, \mathrm{Ni}, \mathrm{Co}$ and $\mathrm{Pb}$ as pollutants of high level, while $\mathrm{Cu}$ and $\mathrm{Zn}$ are at low level. Generally, the distribution of heavy metals in Manzala Lake revealed that the agricultural drains represented by El-Serw drain and the Industrial district represented by Port Said country and 

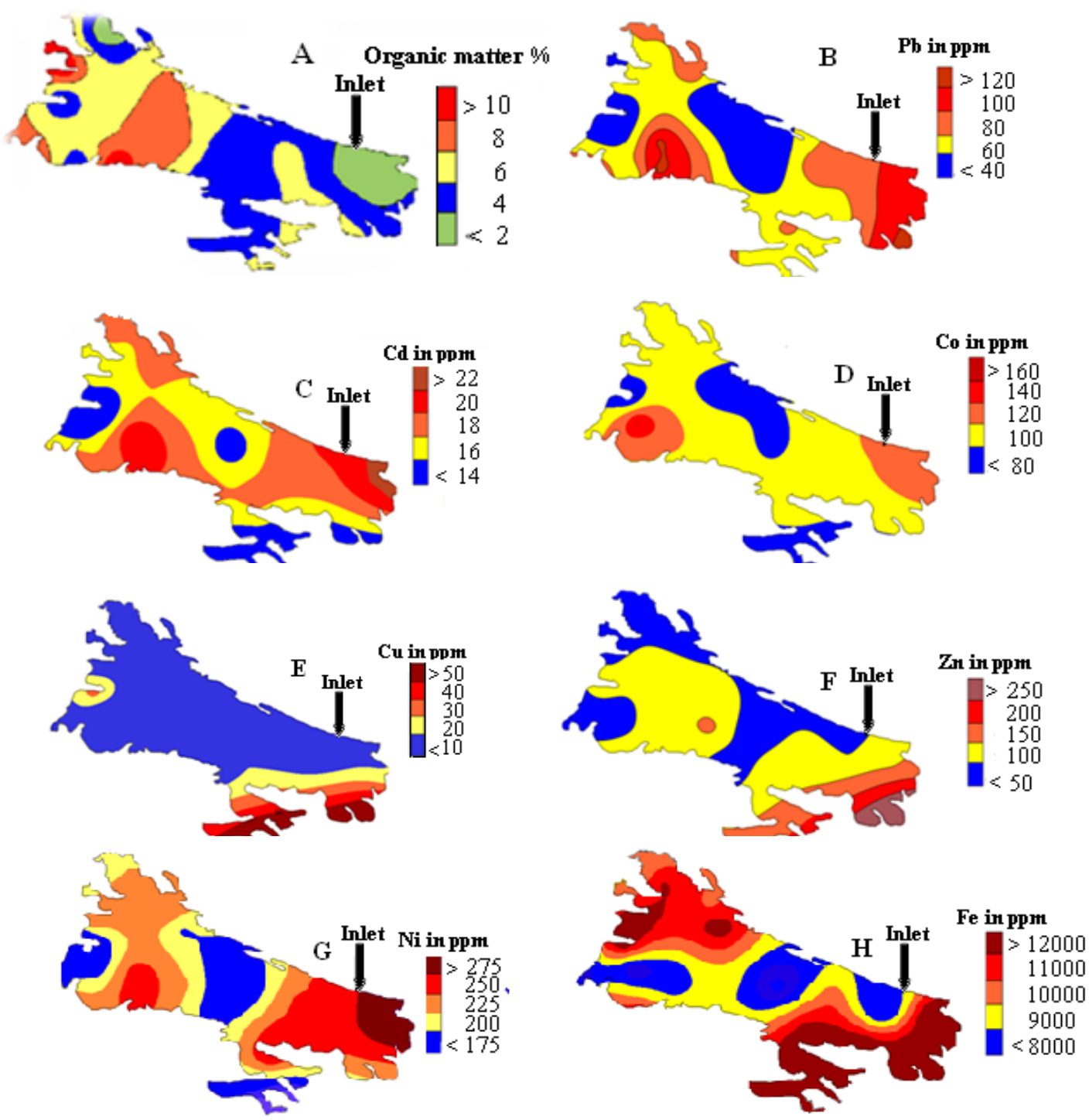

Figure 5: Geochemical maps of heavy metals in the studied bottom lake sediment: (A) Organic matter \%, (B) Lead, (C) Cadmium, (D) Cobalt, (E) Cupper, (F) Zinc, (G) Nickel, and (H) Iron (ppm).

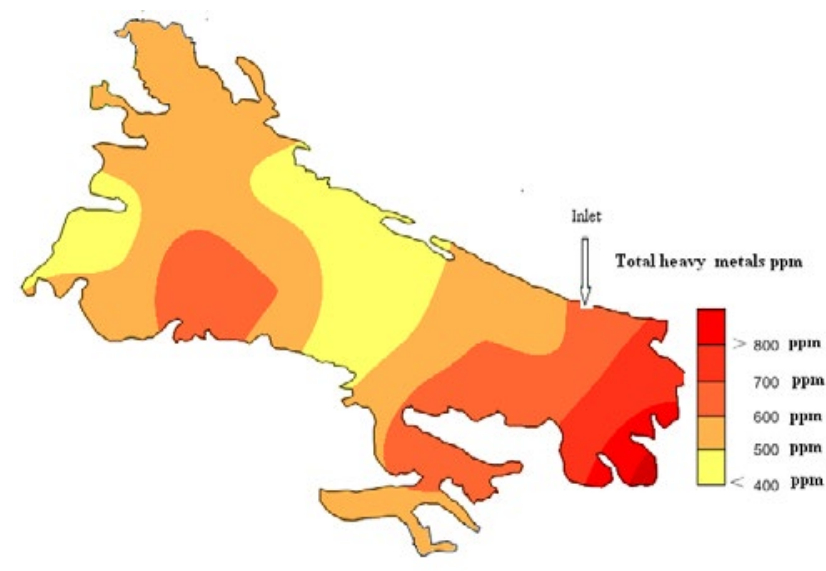

Figure 6: Geochemical map of total heavy metals (ppm) in the studied lake bottom sediments. fishing boats seem to be main source of pollution. The relative order of abundance of elements in lake water is $\mathrm{Pb}>\mathrm{Cu}>\mathrm{Zn}>\mathrm{Cd}$, while the relative order in bottom lake sediments is $\mathrm{Fe}>\mathrm{Ni}>\mathrm{Zn}>\mathrm{Co}>\mathrm{Pb}>\mathrm{Cu}>\mathrm{Cd}$.

\section{References}

1. El-Wakeel SK, Wahby SD (1970) Bottom sediments of Manzala Lake, Egypt J Sed Pet 48: 480-496.

2. Abdel-Mouti MAR (1985) Studies on the chemistry of Manzala lake waters, Egypt. PhD Thesis, Faculty of Science, Alexandria University, Egypt.

3. Abdel-Mouti MAR, Dowidar NM (1988) Trace elements status in surficial sediments of Manzala lake, Egypt. Bull Nat Inst Ocean \& Fish ARE 14: 183202.

4. El-Sabrouti MA, Mahmoud B (1990) Texture, Chemistry and mineralogy of Lake Manzalah sediments, Egypt. Rapp Comm int Mer Medit 33: 129.

5. Hussein KA (1997) Environmental Studies of Lake Manzala, Geological and Environmental Aspect of Coastal Region. p: 9.

6. Abdel-Satar AM (1998) Environmental studies on the impact of the drains effluent upon the southern sector of Lake Manzala, Egypt. J Aquat Biol \& Fish 5: $17-30$. 
Citation: El-Badry AEA (2016) Distribution of Heavy Metals in Contaminated Water and Bottom Deposits of Manzala Lake, Egypt. J Environ Anal Toxicol 6: 344. doi:10.4172/2161-0525.1000344

7. Dewidar $\mathrm{KH}$, Khedr A (2001) Water quality assessment with simultaneous Landsat-5 TM at Manzala Lagoon, Egypt. Hydrobiologia 457: 49-58.

8. Lotfy IMH (2001) Geochemical studies on recent sediments of Manzala Lake, Egypt. J Egypt German Soc Zool 34: 57-76.

9. Lotfy IMH (2007) Heavy metals in water and sediments of lake Manzala, Egypt. J Aquat Biol \& Fish 11: 257-267.

10. Abdalla MAH (2003) Study of natural radioactivity, environmental isotopes and hydrochemistry of some northern lakes in Egypt. PhD Thesis, Faculty of Science, Cairo University, Egypt.

11. Orabi OH, Osman MF (2015) Evaluation of Some Pollution at Manzala Lagoon: Special Reference to Medical Importance of Mollusca in Egypt. J Environ Anal Toxicol 5: 311

12. APHA (1998) Standard Methods for Examination of Water and Wastewater, American Public Health Association Inc. Washington DC. 20th edn, USA.

13. McLennan SM, Taylor SR (1999) Earth's continental crust. In Marshall CP, Fairbridge RW (eds.) Encyclopedia of Geochemistry. Kluwer Academic Publishers, Dordrecht, The Netherlands. pp: 145-151.

14. Kabata-Pendias A (1995) Agricultural problems related to excessive trace metals content of soil. In: Heavy metals (problem and solutions). Salomons W, Förstner U, Mader P (Eds.) Springer-Verlag, Berlin, Heidelberg, New York, London, Tokyo. pp: 3-18.
15. Ghallb MHM (2007) Effect of the drains effluents on the chemical conditions of Lake Manzala and el-Salam canal, Egypt. PhD Thesis, Faculty of Science, Ain Shams. University, Egypt.

16. Kabata-Pendias A, Dudka S, Chlopecka A, Gawinowska T (1992) Background levels and environmental influences on trace metals in soil of the temperate humid zone of Europe. Adriano I (ed.) Biogeochemistry of trace metals. CRC Press, Boca Raton. Florida, USA. pp: 61-84.

17. Mason B, Moore CB (1982) Principles of Geochemistry. 4th edn. Wiley, New York, USA.

18. El-Kammar AM, Ali BH, El-Badry AMM (2009) Environmental Geochemistry of River Nile Bottom Sediments between Aswan and Isna, Upper Egypt. J App Sci Res 5: 585-594.

19. Salomons W, Forstner U (1984) Metals in the Hydrocycle. Springer Verlag. Berlin. p: 349

20. Taylor SR, McLennan SM (1995) The geochemical evolution of the continental crust. Rev Geophys 33: 241-265.

21. USPH (1997) Toxicological profile for zinc and lead on CD-ROM. Agency for Toxic Substances and Disease Registry. US Public Health Service.

22. USEPA (US Environmental Protection Agency) (1997) The incidence and severity of sediment contamination in surface water of the United States. Volume 1: National Sediment Quality Survey. Washington DC. Report 823 . 97- 006. 